\title{
Investigating the effect of the deep cryogenic heat treatment on the corrosion behavior of the 1.2080 tool steel
}

\author{
K. Amini ${ }^{1 *}$, A. Akhbarizadeh ${ }^{2}$, S. Javadpour ${ }^{3}$ \\ ${ }^{1}$ Department of Mechanical Engineering, Tiran Branch, Islamic Azad University, Isfahan, Iran \\ ${ }^{2}$ Department of Materials Science and Engineering, Shiraz Branch, Islamic Azad University, Shiraz, Iran \\ ${ }^{3}$ Department of Materials Science and Engineering, Shiraz University, Shiraz, Iran
}

Received 19 May 2015, received in revised form 8 December 2015, accepted 8 December 2015

\begin{abstract}
Deep cryogenic heat treatment is a supplementary process performed on a vast variety of materials, including tool steels, carburized steels, tungsten carbide, magnesium alloys, and polymers. This process improves the wear behavior and the working life of these materials. This study has investigated the effect of the deep cryogenic heat treatment on the corrosion behavior of the 1.2080 tool steel in different holding durations via the electrochemical impedance spectroscopy (EIS) and linear polarization test (TAFEL) in the environment of 3.5 wt.\% $\mathrm{NaCl}$ aqueous solution. Results show that cryogenic heat treatment decreases the corrosion resistance of the tool steels as a consequence of increasing the carbide percentage as well as improving the carbide distribution. This phenomenon decreases the dissolved chromium atoms which are the major components in corrosion resistance of the tool steels.
\end{abstract}

Ke y words: 1.2080 tool steel, carbide distribution, corrosion resistance, deep cryogenic heat treatment

\section{Introduction}

Cryogenic heat treatment was introduced to the industries during the second and third decades of the 20th century [1]. During the cryogenic heat treatment, samples are cooled down to low temperatures, commonly liquid nitrogen temperature, at a slow cooling rate to prohibit severe distortion and thermal shock damages. Afterward, the samples are held at liquid nitrogen for some periods of time and then gradually warmed up to room temperature. This process is performed quickly after quenching and before tempering $[2,3]$.

During the deep cryogenic heat treatment, the carbon atoms are forced to jump to the nearby defects. These defects involve twins, dislocations and other defects which act as preferential sites for the wandering carbon atoms [4-11]. The $c / a$ ratio value of martensite during cooling and warming does not show equivalent variation. This behavior is a consequence of atom jumping during the holding periods and warming up from the deep cryogenic temperature. This jumping relieves the tetragonality of martensite and produces carbide during the subsequent tempering. The stress relief during the deep cryogenic temperature is another evidence for carbon segregation via jumping to adjacent defects during the deep cryogenic treatment $[12]$.

The carbon atoms would produce eta $(\eta)$ chromium carbides, which are completely different in their structure with regular epsilon $(\varepsilon)$ ones [13]. The newly formed carbides increase the carbide percentage and produce a more homogeneous carbide distribution [1417]. The higher carbide percentage, retained austenite reduction and a more homogeneous carbide distribution increase the hardness and improve the wear resistance of the steel samples from small percentages up to considerably high values (Table 1$)[12,18]$.

Two most important factors in the deep cryogenic heat treatment are the soaking temperature and soaking time. Soaking temperature refers to the temperature that the sample is held for some period. This variable is the most important factor in the deep cryogenic heat treatment, and almost all of the researchers 
Table 1. Properties of DCT samples

\begin{tabular}{lcccc}
\hline $\begin{array}{l}\text { Sample } \\
\text { nomination }\end{array}$ & $\begin{array}{c}\text { Hardness } \\
(\mathrm{MPa})\end{array}$ & $\begin{array}{c}\text { Chromium carbide } \\
\text { percentage } \\
(\text { vol.\%) }\end{array}$ & $\begin{array}{c}\text { Chromium carbide } \\
\text { grain boundary length } \\
(\mu \mathrm{m})\end{array}$ & $\begin{array}{c}\text { Average chromium } \\
\text { carbide size } \\
(\mu \mathrm{m})\end{array}$ \\
\hline CHT & $920 \pm 16$ & 18 & 469 & 2.05 \\
DCT24 & $980 \pm 12$ & 23.1 & 501 & 1.71 \\
DCT36 & $1020 \pm 14$ & 26.3 & 646 & 1.55 \\
DCT48 & $1008 \pm 12$ & 24.1 & 561 & 1.62 \\
DCT72 & $1004 \pm 14$ & 24 & 580 & 1.64 \\
DCT96 & $1005 \pm 11$ & 24.3 & 572 & 1.60 \\
DCT120 & $1010 \pm 10$ & 24.1 & 576 & 1.63 \\
\hline
\end{tabular}

showed that decreasing the temperature down to liquid nitrogen temperature, improves the wear resistance, hardness and carbide percentage significantly as compared with those of the higher temperatures (shallow cryogenic) [4, 19-21]. Soaking time refers to the period that the sample is held at the cryogenic temperature. This period can vary from some minutes [22] to some hours [10, 15, 23-25]. Some researchers showed that increasing the holding time improves the wear behavior due to its effect on the nucleation of more carbides during tempering $[10,26]$. Despite these results, some researchers showed that increasing the hardness and wear resistance has an optimum value and after that, increasing the holding duration, the wear resistance and hardness decrease continuously [19, 27].

Despite these studies, there is a lack of investigations about the effect of the deep cryogenic heat treatment on the corrosion behavior of the tool steel. In the earliest studies, we showed that the deep cryogenic heat treatment has an optimum holding duration for the DIN 1.2080 tool steel in which the hardness shows its highest value. In this study, the effect of the deep cryogenic heat treatment on the corrosion behavior of AISI 1.2080 grade steel which is vastly used in die-making was investigated via the electrochemical impedance spectroscopy (EIS) and linear polarization test (TAFEL).

\section{Experimental}

A commercial 1.2080 tool steel bar with the diameter of $20 \mathrm{~mm}$ and the nominal composition of $\mathrm{Cr} 12 \%$, $\mathrm{W} 1 \%$, V $0.5 \%$, C $1.8 \%$, Si $0.3 \%$ and Fe $84.4 \%$ was cut into disks with the height of $5 \mathrm{~mm}$. For conventional heat treatment, the samples were austenitized in an electrical furnace at $950^{\circ} \mathrm{C}$ and in the vacuum environment for $15 \mathrm{~min}$ and then quenched in oil. Some of the samples were kept away at room temperature for further analyses, and the rest of the samples were cryogenically treated in different situations including different holding durations. For cryogenic heat treatment, the samples were cooled down to $-195^{\circ} \mathrm{C}$, held at that temperature for some periods and then warmed up to room temperature with the cooling and heating rate of $2^{\circ} \mathrm{C} \mathrm{min}^{-1}$. The samples were held for different periods of time including 24, 36, 48, 72, 96, and $120 \mathrm{~h}$ and were named deep cryogenically treated samples, DCT24, DCT36, DCT48, DCT72, DCT96, and DCT120, respectively. After that, all of the samples were tempered at $180^{\circ} \mathrm{C}$ for $3 \mathrm{~h}$ in an electric oven. The samples were then analyzed via the $\mathrm{X}$-ray diffraction machine (XRD) and scanning electron microscope (SEM) to evaluate the retained austenite percentage and study the microstructural changes of the samples [28]. For more studies the samples were etched in 1$100 \mathrm{ml} \mathrm{H}_{2} \mathrm{O}, 10 \mathrm{~g} \mathrm{~K}_{3} \mathrm{Fe}(\mathrm{CN})_{6}$ and $10 \mathrm{~g} \mathrm{NaOH}, 2$-Mixed acid and 3-Nital $4 \%$ etchants. This combination of etchants darkens the carbide, and this phase can be clarified precisely. For a more accurate calculation of the distribution of carbides, the carbides which were bigger than $0.5 \mu \mathrm{m}$ were colored in Photoshop CS5 software to be distinguished better than the substrate. After that, the image-analyzing software (Clemex Vision version 3.5.025 and ImageJ/FIJI 1.46) were used to calculate the average particle size and the length of chromium carbide grain boundaries regarding at least 3 micrographs in each sample.

The retained austenite and martensite percentage were calculated regarding the ASTM E975-00 standard. After that the hardness of the samples was analyzed via a COOPA MH1 microhardness tester equipped with a Vickers indenter under a load of $500 \mathrm{gf}$ and a load exertion time (dwell time) of $15 \mathrm{~s}$.

The corrosion resistance of the samples was determined using potentiodynamic polarization test. The polarization measurements were carried out with a scan rate of $1 \mathrm{mV} \mathrm{s}^{-1}$ using an Autolab potentiostat model type 3, EcoChemie BV and a General Purpose Electrochemical System 4.9 software. It was conducted in a 3.5 wt.\% $\mathrm{NaCl}$ aqueous solution using a classic three-electrode cell with a platinum plate as the 
counter electrode and an $\mathrm{Ag} / \mathrm{AgCl}$ electrode as the reference electrode. The samples were cleaned in acetone and then drawn in deionized water before the electrochemical test. The samples were covered with lacquer so that only $1 \mathrm{~cm}^{2}$ area was exposed to the electrolyte. The specimens were immersed in the mentioned solution for $120 \mathrm{~min}$ at room temperature to reach a steady state. After that the samples were transferred into the test holder and then remained for $1500 \mathrm{~s}$ to calculate the OCP (Open Circuit Potential). The samples were then analyzed in the range of -250 to $+250 \mathrm{mV}$ with respect to the OCP $[29,30]$. The $I_{\text {corr }}$ and $E_{\text {corr }}$ were then calculated with respect to an anodic and cathodic branch of the Tafel test $[29,30]$. Each test was carried out for 2-3 times to reach a trustful average. The corrosion rates of the samples were analyzed regarding Eq. (1):

$$
\mathrm{MPY}=i_{\text {corr }}(\Delta)(2 / \rho)(\varepsilon)
$$

where MPY is the corrosion rate $\left(\mathrm{mm} y e a r^{-1}\right), \Delta$ is $1.2866 \times 10^{3}$ (equivalents. sec. mils) (Coulombs cm year $)^{-1}, i_{\text {corr }}$ is the corrosion electric current in $\mathrm{A} \mathrm{cm}^{-2}, \rho$ is density in $\mathrm{g} \mathrm{cm}^{-3}$, and $\varepsilon$ is equivalent weight in grams equivalents [29].

For more studies the cyclic test was also performed on the samples to show the corrosion behavior more accurately. For this purpose, the samples were prepared as the samples for the potentiodynamic polarization examination. After that the samples were transferred into the test holder and then remained for 1500 s to calculating the OCP (Open Circuit Potential). The samples were then examined in the range of $-250 \mathrm{mV}$ to $+2 \mathrm{~V}$ with respect to the OCP via the Autolab potentiostat model type 3, and with a scan rate of $1 \mathrm{mV} \mathrm{s}^{-1}$. The test was conducted in a 3.5 wt. $\% \mathrm{NaCl}$ aqueous solution using a classic threeelectrode cell with a platinum plate as the counter electrode and an $\mathrm{Ag} / \mathrm{AgCl}$ electrode as the reference electrode.

The EIS test was performed in the frequency range of 0.001 to $100000 \mathrm{~Hz}$ and the voltage amplitude of $10 \mathrm{mV}$. The samples were analyzed via Autolab potentiostat model type 3, EcoChemie BV and Fra software. After data fitting, the simulated circuit was evaluated via the experimental observations.

The most common method used to analyze EIS spectra is Equivalent Electrical Circuit Modeling. In this simulation approach, the behavior of each element is described in terms of "classical" electrical components (resistors, capacitors, inductors) plus a few specialized electrochemical elements (like Warburg diffusion elements). In this study, Equivalent Circuit Modeling of EIS was conducted by the FRA Software including Model Editor that allows building an equivalent circuit model.

\section{Results and discussion}

As it was shown in the earlier works [28], the retained austenite was reduced from $13 \%$ (vol.\%) to below the detection limit of the XRD method ( $<1 \mathrm{wt} . \%)$ due to the deep cryogenic heat treatment. It was also revealed that the carbide distribution was varying in different holding durations at the deep cryogenic temperature. The hardness of the samples was increased continuously in the beginning periods of the deep cryogenic heat treatment up to the $36 \mathrm{~h}$ holding durations. This behavior is a consequence of increasing the carbide percentage as well as reaching a more uniform carbide distribution in a longer holding duration (Fig. 1 and Table 1). In longer holding durations $(<36 \mathrm{~h})$, the microhardness of the samples was decreased due to a decrease in the carbide percentage and a weaker carbide distribution as compared to the DCT36 samples (Fig. 1 and Table 1). After an optimum holding duration $(36 \mathrm{~h})$, this increase in the microhardness ended and decreased in longer holding duration due to the bigger carbides size, weaker carbides distribution, and fewer carbides percentage. This reduction in the carbide percentage and a less homogeneous distribution are a consequence of the bigger carbides produced during the deep cryogenic treatment in longer holding durations (Fig. 1 and Table 1). The bigger carbides prohibit the formation of the fine carbides and subsequently the carbide percentage decreases. After the carbides percentage had decreased, microhardness and carbides distribution reached a constant value and did not change vividly after $48 \mathrm{~h}$ holding duration (Fig. 1 and Table 1).

Potentiodynamic polarization curves of the conventionally and deep cryogenically treated samples in the 3.5 wt. $\% \mathrm{NaCl}$ solution are shown in Fig. 2. It can be observed that deep cryogenic heat treatment declined the corrosion resistance of the 1.2080 tool steel for $54 \%$ in the DCT24 sample as compared with CHT one. Increasing the holding duration at the deep cryogenic temperatures leads to a continuous decrease in the corrosion resistance of the DCT samples up to $36 \mathrm{~h}$ holding duration. After that the corrosion resistance (corrosion rate) reached a steady value at $48 \mathrm{~h}$ samples (DCT48) and after that does not change considerably (Fig. 2). Table 2 shows that deep cryogenic heat treatment changes the current densities to more positive values as well as decreases the potentials to lower values.

The impedance spectroscopy of the CHT and DCT samples is shown in Fig. 3. The equivalent electrical circuit of the samples was drawn, and it was clarified that all of the samples show a one capacitive loop (Fig. 3d). In this diagram the $R_{\mathrm{S}}$ is the solution resistance between the sample and the reference electrode, $R_{1}$, is the charge transfer resistance, $C$ is the double layer capacitance and $n$ shows the deviation 

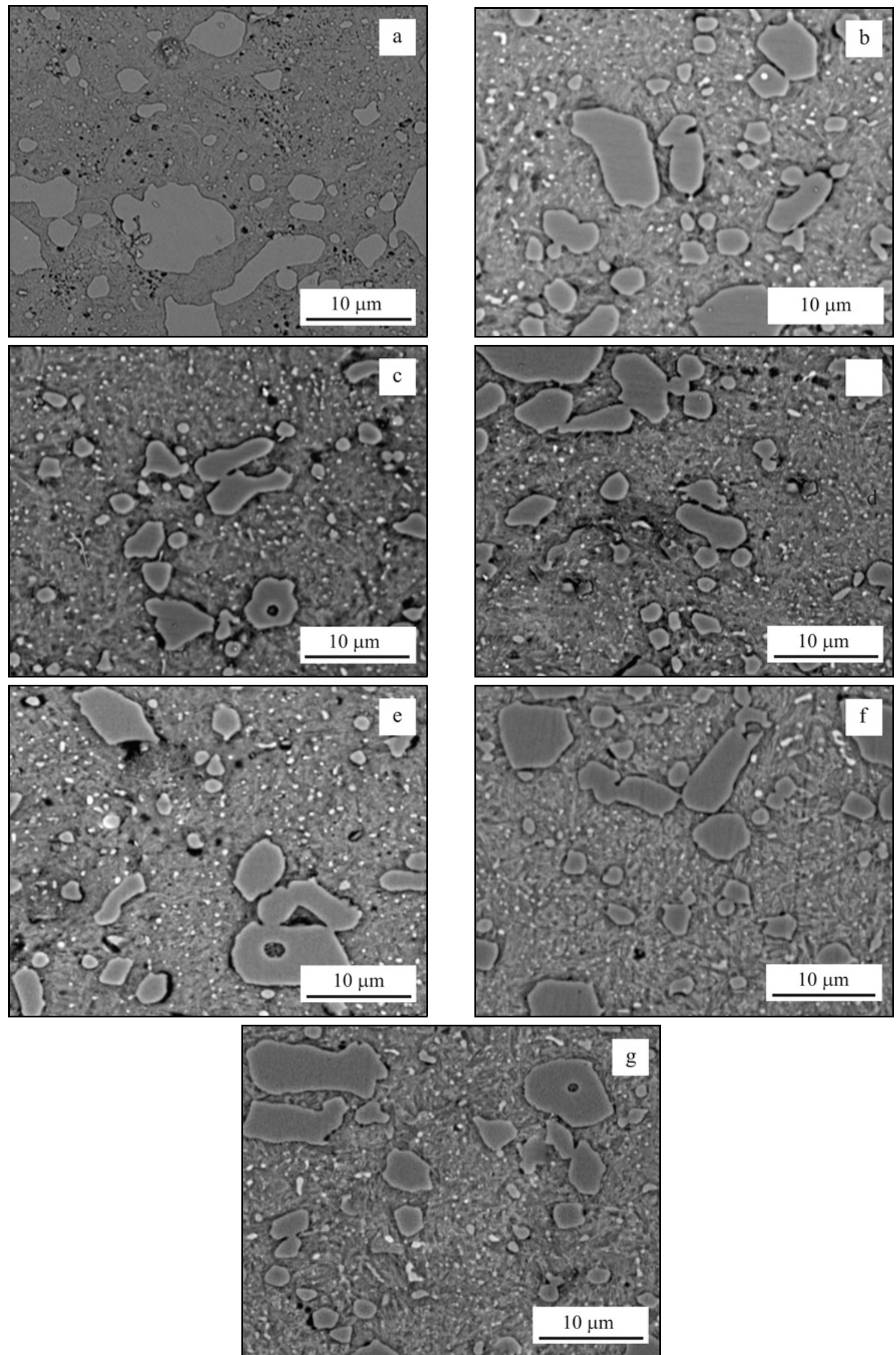

Fig. 1. SEM micrograph of the (a) CHT, (b) DCT24, (c) DCT36, (d) DCT48, (e) DCT72, (f) DCT96 and (g) DCT120 samples at $1500 \times$. 


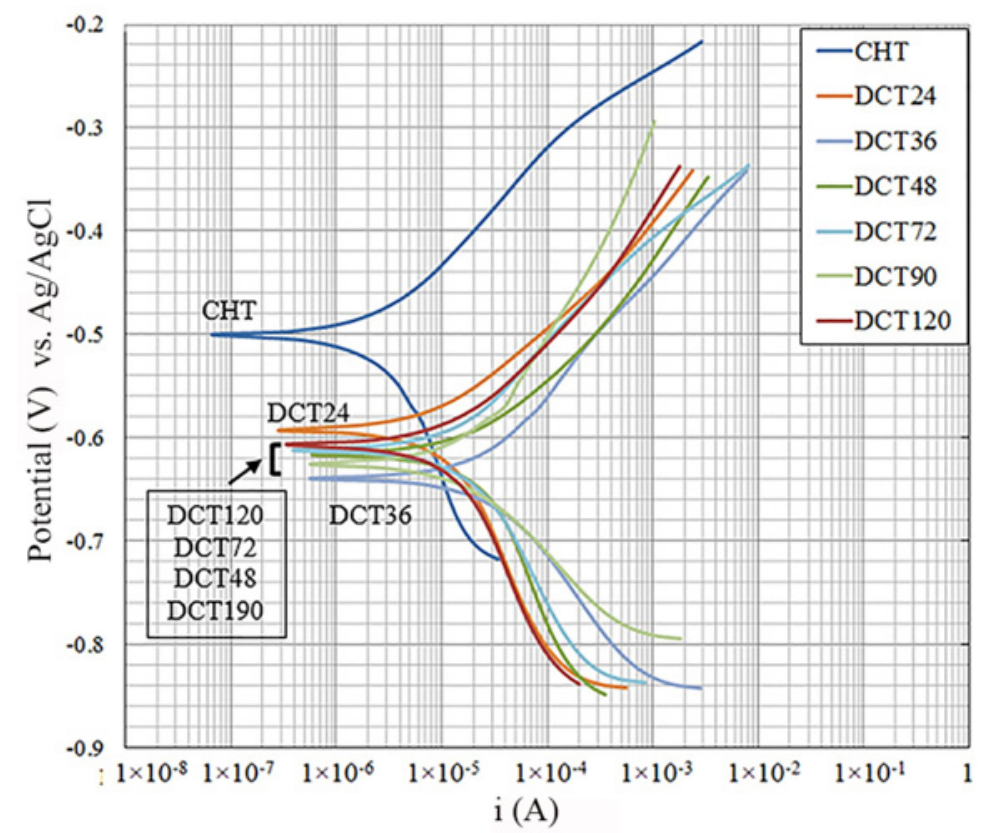

Fig. 2. Polarization curve of samples at different holding durations in 3.5 wt. $\% \mathrm{NaCl}$ solution and via the $\mathrm{Ag} / \mathrm{AgCl}$ electrode.

Table 2. Calculated parameters for polarization diagram from different samples in $3.5 \mathrm{wt} . \% \mathrm{NaCl}$ solution and via the $\mathrm{Ag} / \mathrm{AgCl}$ electrode

\begin{tabular}{|c|c|c|c|c|c|c|}
\hline $\begin{array}{l}\text { Samples } \\
\text { nomination }\end{array}$ & $\begin{array}{l}\mathrm{OCP} \\
(\mathrm{V})\end{array}$ & $\begin{array}{c}I_{\text {corr }} \\
\left(\mathrm{A} \mathrm{cm}^{-2}\right)\end{array}$ & $\begin{array}{c}\beta_{\mathrm{c}} \\
\left(\mathrm{V} \mathrm{\operatorname {dec } ^ { - 1 }}\right)\end{array}$ & $\left(\begin{array}{c}\beta_{\mathrm{a}} \\
\left(\mathrm{V} \mathrm{\operatorname {dec } ^ { - 1 }}\right)\end{array}\right.$ & $\begin{array}{c}E_{\text {corr }} \\
(\mathrm{V})\end{array}$ & $\begin{array}{c}\text { Corrosion rate } \\
\left(\mathrm{mm} \mathrm{year}^{-1}\right)\end{array}$ \\
\hline $\mathrm{CHT}$ & -0.467 & 0.000001323 & 0.112 & 0.067 & -0.501 & 0.01554 \\
\hline DCT24 & -0.592 & 0.000006 & 0.077 & 0.115 & -0.592 & 0.0694 \\
\hline DCT36 & -0.592 & 0.00001724 & 0.135 & 0.128 & -0.639 & 0.0996 \\
\hline DCT48 & -0.588 & 0.00000721 & 0.082 & 0.056 & -0.607 & 0.08337 \\
\hline DCT72 & -0.587 & $7.0702 \mathrm{E}-06$ & 0.072 & 0.078 & -0.612 & 0.08165 \\
\hline DCT90 & -0.544 & $6.762 \mathrm{E}-09$ & 0.067 & 0.064 & -0.625 & 0.078351 \\
\hline DCT120 & -0.598 & $6.9925 \mathrm{E}-06$ & 0.094 & 0.065 & -0.616 & 0.080825 \\
\hline
\end{tabular}

from ideal capacitance $(n=1)$. The size of the loop is a function of corrosion resistance of the samples. In other words, increasing the loop diameter leads to a decrease in the corrosion rate [31]. Similarly, the diameter of the loop shows the charge transfer resistance [32]. The loop of the DCT samples is smaller than that of the CHT ones and hence the corrosion rate increases due to the deep cryogenic heat treatment (Fig. 3). The calculated parameters of impedance diagram are shown in Table 3 . Deep cryogenic heat treatment forces carbon atoms to jump to nearby defects and subsequently increases the carbides percentage due to the formation of newly formed carbides during tempering in the carbon atoms high population sites. This movement is a consequence of highly distorted martensite structure that forces carbon atoms to jump to nearby defect. These defects attract carbon atoms from the saturated and contracted martensite struc- ture. The newly formed carbides increase the carbide percentage and make a more homogeneous distribution $[2,8,21,33,34]$. Increasing the carbide percentage leads to a decrease in the solutionized chromium atoms in the structure. The chromium atoms are the major elements in increasing the corrosion resistance of the steels. The chromium atoms improve the corrosion resistance considerably when they exist in the structure as the free atoms to produce the protective oxide film $[35,36]$. Deep cryogenic heat treatment decreased the free chromium atoms and subsequently declined the corrosion resistance noticeably (Tables 2 and 3). Moreover, increasing the carbides percentage leads to an increase in the chromium carbide grain boundaries which would act as the galvanic cell during the corrosion. The grain boundaries are the high energy areas, and hence increasing the grain boundaries leads to an increase in the corrosion rate of the 

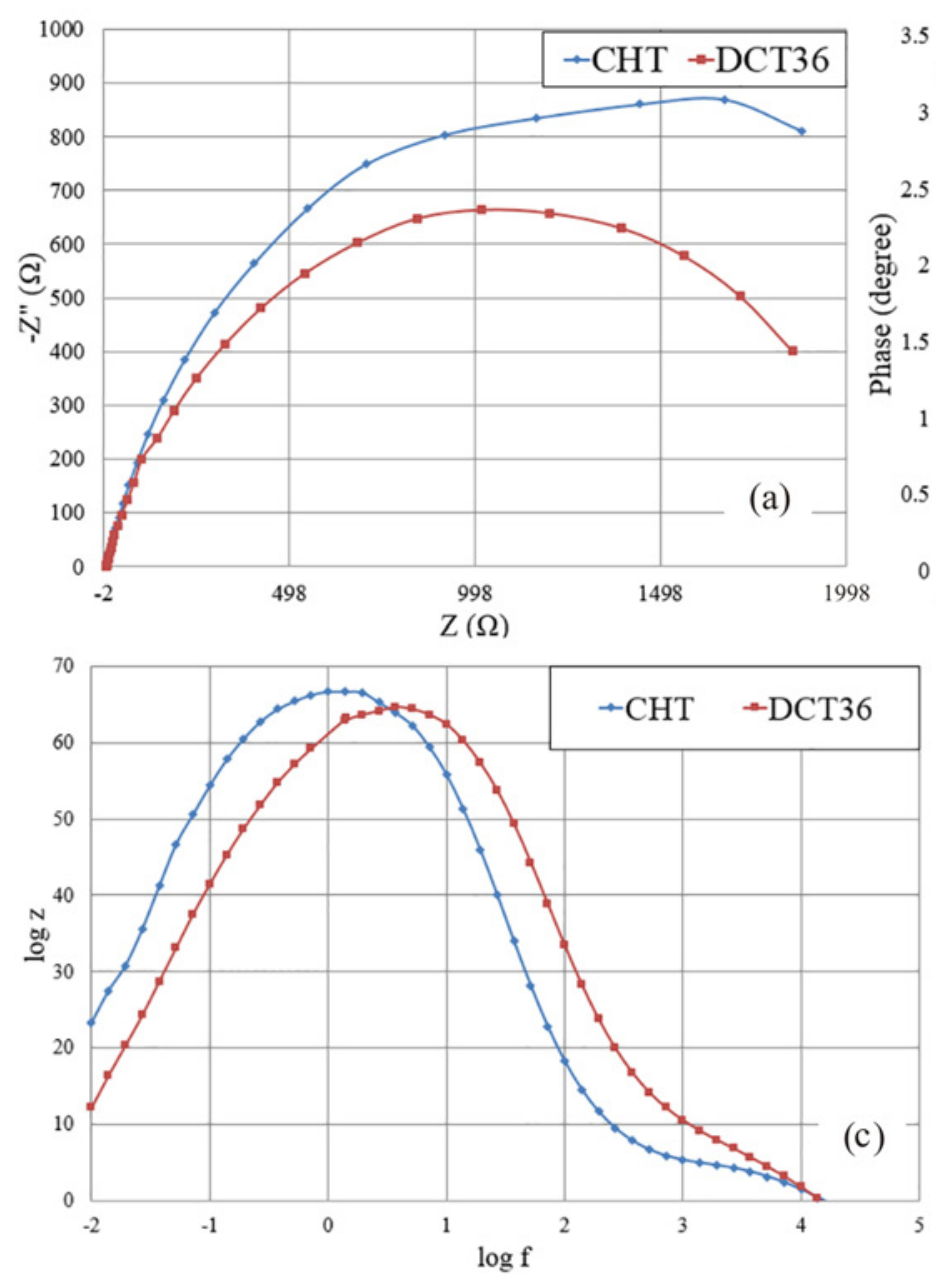
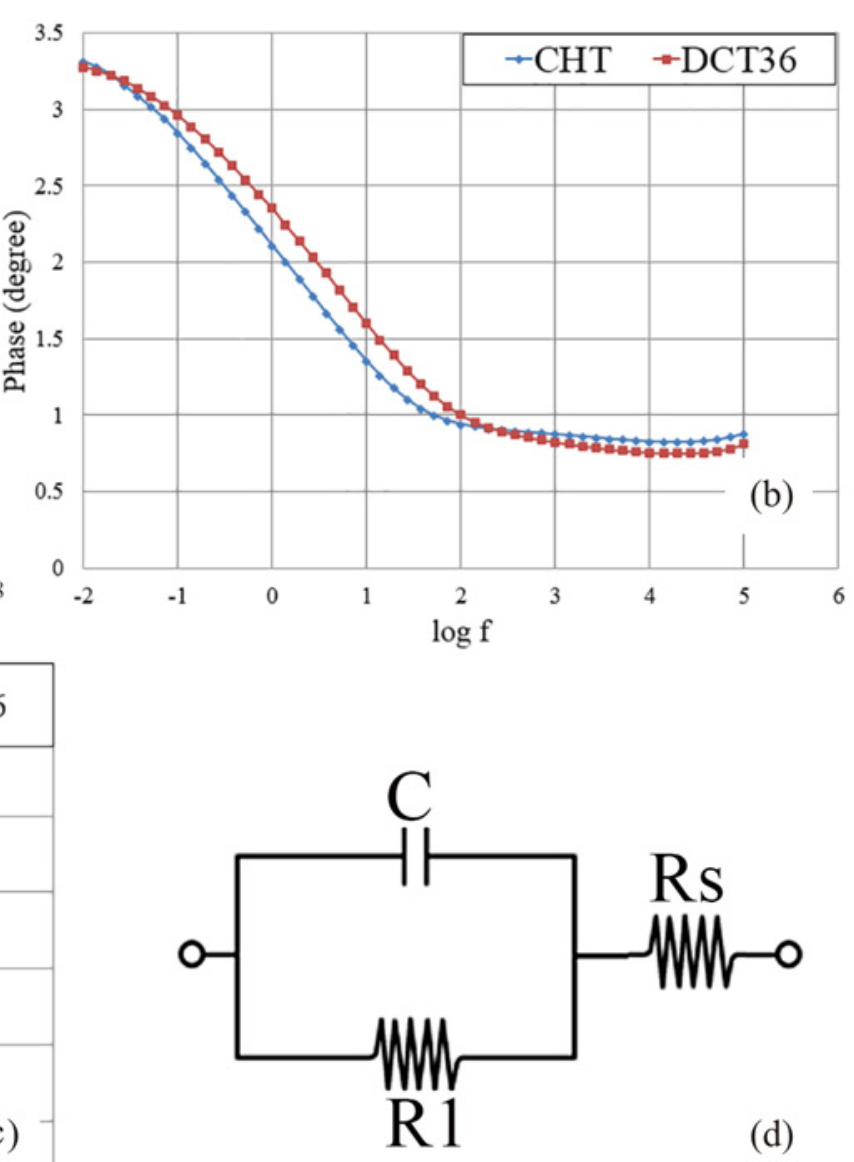

Fig. 3. Electrochemical spectroscopy diagram of CHT and DCT36 samples: (a) Nyquist plots, (b) Bode phase angle, (c) Bode impedance via the $\mathrm{Ag} / \mathrm{AgCl}$ electrode and (d) equivalent circuit.

Table 3. Calculated parameters from impedance spectroscopy in $3.5 \mathrm{wt} . \% \mathrm{NaCl}$ solution

\begin{tabular}{lccccc}
\hline Samples nomination & $R_{1} / \Omega$ & $Q / F$ & $R_{\mathrm{s}} / \Omega$ & $n$ & $R_{1}+R_{\mathrm{s}} / \Omega$ \\
\hline CHT & 2397 & 0.001816 & 7 & 0.8049 & 2404 \\
DCT24 & 2150 & 0.001987 & 7.11 & 0.8374 & 2157.11 \\
DCT36 & 1983 & 0.001104 & 6.86 & 0.7692 & 1989.86 \\
DCT48 & 2009 & 0.001987 & 7.11 & 0.8371 & 2016.11 \\
DCT72 & 1997 & 0.001823 & 6.92 & 0.8326 & 2003.92 \\
DCT90 & 2011 & 0.001861 & 7.06 & 0.8239 & 2018.06 \\
DCT120 & 2003 & 0.001923 & 7.09 & 0.8265 & 2010.09 \\
\hline
\end{tabular}

deep cryogenically treated samples. Hence, the corrosion rate of the samples with fine carbides is increased due to the more grain boundaries as potential sites for increasing the corrosion rate. It is worth mentioning that some studies showed that chromium carbide improves the corrosion resistance of steels [37, 38], but this improvement is negligible as compared with the chromium oxide.

In the longer holding durations, the carbide percentage increased at the initial times. This behavior is due to the further structure contraction, in longer holding durations in which the structure is distorted additionally, and subsequently more carbon atoms jumped to the nearby defects. This phenomenon increases the carbide percentage and subsequently decreases the dissolved chromium atoms in the structure and increases the grain boundary of the chromium carbide. In other words, increasing the holding duration decreased the corrosion rate considerably from 0.0694 to $0.0996 \mathrm{~mm}$ year $^{-1}$ in the DCT36 samples as 


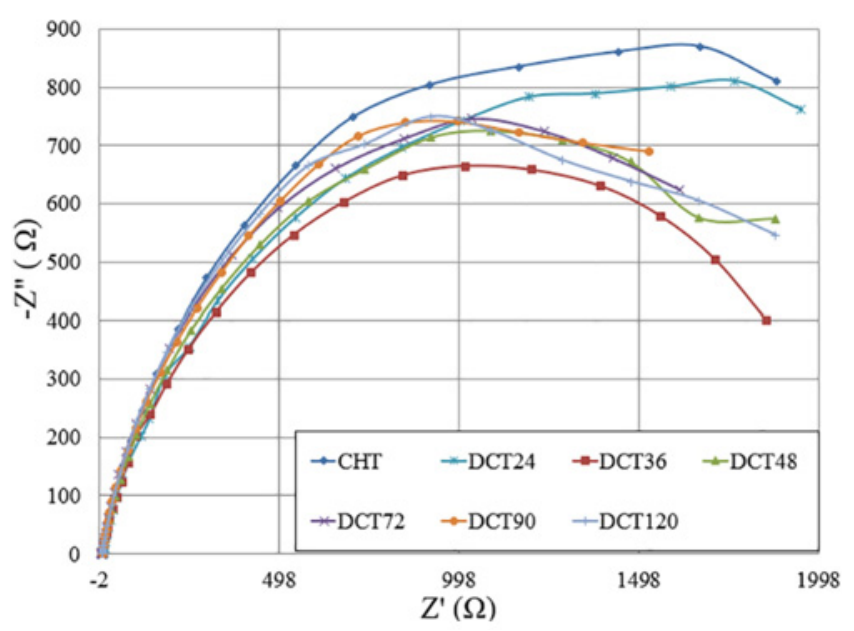

Fig. 4. Nyquist plots of electrochemical impedance spectroscopy diagram of samples in 3.5 wt. $\% \mathrm{NaCl}$ solution and via the $\mathrm{Ag} / \mathrm{AgCl}$ electrode.

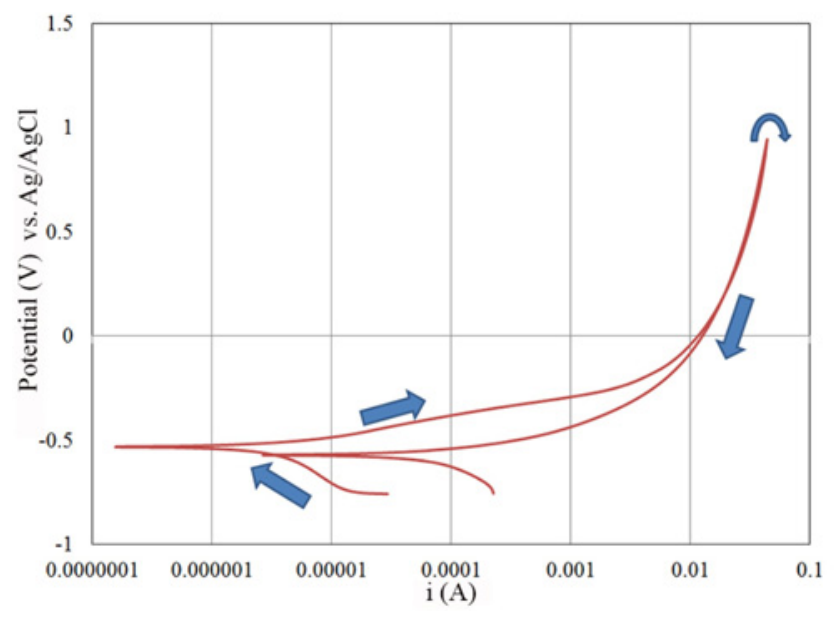

Fig. 5. Cyclic polarization curve of the DCT24 sample.

compared with the DCT24 ones. Beyond $36 \mathrm{~h}$ holding duration, the carbon atom clusters become bigger in colonies and subsequently bigger carbides were produced instead of finer and more homogeneously distributed ones [39]. An increase in carbides size takes the chance of other new carbides to nucleate and grow. In the places which are close to big carbides, the population of small carbides decreases vividly because big carbides attract carbon atoms of smaller ones in the surrounded areas and subsequently big and localized carbides alternate the small and distributed carbides. Hence, the corrosion rate increases initially in the DCT48 samples as compared with the DCT36 ones and does not change vividly in longer holding durations (Fig. 4 and Table 3).

For more studies the cyclic test was also performed on the samples to show the corrosion behavior more accurately (Fig. 5). Anodic branch of a polarization test shows a return path regularly. If the return path turns counterclockwise and interrupts the anodic branch, the sample is susceptible to the pitting corrosion. On the other side, if the return path turns counterclockwise and does not interrupt the anodic branch, the pitting corrosion is not possible [40]. Figure 5 shows that the return path turns in the clockwise mode and interrupts the anodic branch. Hence, the pitting is the predominant corrosion mechanism in 3.5 wt. $\% \mathrm{NaCl}$ solution. Beyond this, the passivation was not observed in the samples due to the low dissolved content of chromium as well as a low corrosivity of the test environment.

\section{Conclusions}

This study was carried out to investigate the effect of the deep cryogenic heat treatment on the microstructure, hardness and corrosion behavior of the DIN 1.2080 tool steel. It can be observed that deep cryogenic heat treatment declined the corrosion resistance of the 1.2080 tool steel by $54 \%$ in the DCT24 samples as compared with the CHT ones. This behavior is a consequence of less dissolved chromium atoms and a more chromium carbide grain boundaries in the deep cryogenically treated samples as compared with the conventionally treated ones. The dissolved chromium atoms are the major components in corrosion resistance of the tool steels. The corrosion resistance decreases continuously up to $36 \mathrm{~h}$ holding duration. After that the corrosion resistance (corrosion rate) reached a steady value at $48 \mathrm{~h}$ samples (DCT48) and after that did not change considerably due to reaching a steady chromium percentage.

\section{References}

[1] Gill, S., Singh, J., Singh, R., Singh, H.: Int. J. Adv. Manuf. Technol., 54, 2011, p. 59. doi:10.1007/s00170-010-2935-5

[2] Amini, K., Nategh, S., Shafyei, A., Rezaeian, A.: Int. J. Min. Met. Mater., 19, 2012, p. 30. doi:10.1007/s12613-012-0511-8

[3] Amini, K., Akhbarizadeh, A., Javadpour, S.: Mater. Design, 45, 2013, p. 316. doi:10.1016/j.matdes.2012.08.006

[4] Akhbarizadeh, A., Amini, K., Javadpour, S.: Mater. Design, 35, 2012, p. 484. doi:10.1016/j.matdes.2011.09.015

[5] Huang, J. Y., Zhu, Y. T., Liao, X. Z., Beyerlein, I. J., Bourke, M. A., Mitchell, T. E.: Mat. Sci. Eng. A, 339, 2003, p. 241. doi:10.1016/S0921-5093(02)00165-X

[6] Amini, K., Akhbarizadeh, A., Javadpour, S.: Int. J. Min. Met. Mater., 19, 2012, p. 795. doi:10.1007/s12613-012-0630-2

[7] Das, D., Dutta, A. K., Ray, K. K.: Wear, 266, 2009, p. 297. doi:10.1016/j.wear.2008.07.001 
[8] Das, D., Dutta, A. K., Ray, K. K.: Mat. Sci. Eng. A, 527, 2010, p. 2182. doi:10.1016/i.msea.2009.10.070

[9] Amini, K., Nategh, S., Shafyei, A.: Mater. Design, 31, 2010, p. 4666. doi:10.1016/j.matdes.2010.05.028

[10] Mohan Lal, D., Renganarayanan, S., Kalanidhi, A.: Cryogenics, 41, 2001, p. 149. doi:10.1016/S0011-2275(01)00065-0

[11] Stratton, P. F.: Mat. Sci. Eng. A, 449-451, 2007, p. 809. doi:10.1016/i.msea.2006.01.162

[12] Bensely, A., Venkatesh, S., Mohan Lal, D., Nagarajan, G., Rajadurai, A., Junik, K.: Mat. Sci. Eng. A, 479, 2008, p. 229. doi:10.1016/j.msea.2007.07.035

[13] Meng, F. T. K., Azuma, R., Sohma, H.: ISIJ Int., 34, 1994, p. 205. doi:10.2355/isijinternational.34.205

[14] Bensely, A., Prabhakaran, A., Mohan Lal, D., Nagarajan, G.: Cryogenics, 45, 2005, p. 747. doi:10.1016/j.cryogenics.2005.10.004

[15] Leskovšek, V., Kalin, M., Vižintin, J.: Vacuum, 80, 2006, p. 507. doi:10.1016/j.vacuum.2005.08.023

[16] Amini, K., Araghi, A., Akhbarizadeh, A.: Acta Metall. Sin. (Engl. Lett.), 28, 2015, p. 348. doi:10.1007/s40195-015-0204-1

[17] Molinari, A., Pellizzari, M., Gialanella, S., Straffelini, G., Stiasny, K. H.: J. Mater. Process. Tech., 118, 2001, p. 350. doi:10.1016/S0924-0136(01)00973-6

[18] Firouzdor, V., Nejati, E., Khomamizadeh, F.: J. Mater. Process. Tech., 206, 2008, p. 467. doi:10.1016/i.jmatprotec.2007.12.072

[19] Darwin, J. D., Mohan Lal, D., Nagarajan, G.: J. Mater. Process. Tech., 195, 2008, p. 241. doi:10.1016/j.jmatprotec.2007.05.005

[20] Paydar, H., Amini, K., Akhbarizadeh, A.: Kovove Mater., 52, 2014, p. 163. doi:10.4149/km 20143163

[21] Kalsi, N. S., Sehgal, R., Sharma, V. S.: Mater. Manuf. Process., 25, 2010, p. 1077. doi:10.1080/10426911003720862

[22] Akhbarizadeh, A., Javadpour, S., Amini, K.: Mater. Design, 45, 2013, p. 103. doi:10.1016/j.matdes.2012.08.012

[23] Oppenkowski, A., Weber, S., Theisen, W.: J. Mater. Process. Tech., 210, 2010, p. 1949. doi:10.1016/j.jmatprotec.2010.07.007
[24] Amini, K., Nategh, S., Shafiey, A., Soltany, M. A.: In: Proceedings of the 17th International Metallurgical and Materials Conference. Ostrava, Tanger 2008, p. 1.

[25] Zhirafar, S., Rezaeian, A., Pugh, M.: J. Mater. Process. Tech., 186, 2007, p. 298. doi:10.1016/j.jmatprotec.2006.12.046

[26] Zurecki, Z.: In: Proceedings of the 23rd Heat Treating Society Conference. Ed.: Herring, D. Materials Park, ASM International 2006, p. 380.

[27] Das, D., Dutta, A. K., Ray, K. K.: Cryogenics, 49, 2009, p. 176. doi:10.1016/i.cryogenics.2009.01.002

[28] Amini, K., Akhbarizadeh, A., Javadpour, S.: Vacuum, 86, 2012, p. 1534. doi:10.1016/j.vacuum.2012.02.013

[29] Tait, W. S.: An Introduction to Electrochemical Corrosion Testing for Practical Engineers and Science. Madison, Pair O Docs Professionals 1994.

[30] Orazem, M. E., Tribollet, B.: Electrochemical Impedance Spectroscopy. Hoboken, John Wiley \& Sons, Inc. 2008.

[31] Song, D., Ma, A. B, Jiang, J. H., Lin P. H., Yang, D. H.: T. Nonferr. Metal. Soc., 19, 2009, p. 1065. doi:10.1016/S1003-6326(08)60407-0

[32] Darmiani, E., Danaee, I., Golozar, M. A., Toroghinejad, M. R.: J. Alloys Compd., 552, 2013, p. 31. doi:10.1016/j.jallcom.2012.10.069

[33] Amini, K., Negahbani, M., Ghayor, H.: Metall. Ital., 3, 2015, p. 53.

[34] Barron, R. F.: Cryogenics, 22, 1982, p. 409. doi:10.1016/0011-2275(82)90085-6

[35] Lula, R. A., Parr, J. G.: Stainless Steel. Michigan, American Society for Metals 2007.

[36] Davis, J. R.: Stainless Steels. Materials Park, ASM International 1994.

[37] Lee, J. W., Duh, J. G., Tsai, S. Y.: Surf. Coat. Technol., 153,2002 , p. 59. doi:10.1016/S0257-8972(01)01546-8

[38] Kamimura, T., Stratmann, M.: Corros. Sci., 43, 2001, p. 429. doi:10.1016/S0010-938X(00)00098-6

[39] Porter, D., Easterling, K. E., Sherif, M. Y.: Phase Transformations in Metals and Alloys. 3rd Edition. New York, CRC Press 2009.

[40] Baboian, R.: Corrosion Tests and Standards. 2nd Edition. West Conshohocken, ASTM International 2005. 